\title{
Effect of Compost Extract Fortified with Tempe on Chili Mosaic Virus Disease
}

\author{
Arumbinang Wajdi ${ }^{1}$, Suwandi Suwandi ${ }^{1,2^{*}}$, Chandra Irsan ${ }^{1}$, A. Muslim ${ }^{1}$, Harman \\ Hamidson $^{1}$
}

\author{
${ }^{1}$ Department of Plant Protection, Faculty of Agriculture, Sriwijaya University, Indonesia \\ ${ }^{2}$ Food Research Center, Institute of Research and Community Services, Sriwijaya University, Indonesia \\ *Corresponding Author: suwandi@fp.unsri.ac.id
}

\begin{abstract}
Mosaic disease caused by multiple infections of viruses in one of the most devastating virus diseases of chili pepper (Capsicum annuum) in Indonesia. Improving plant resistance by treatment with exogenous bioactive compounds is promisingly developed for plant protection in organic chili production. We demonstrated the suppressive effects of a fermented water extract of compost fortified with over-fermented tempe (TCE) on mosaic disease and its aphid vector. TCE was applied weekly by foliar spraying at 0.2 and $2.0 \%$ on potted Capsicum growing in field. The result showed that treated plant sprayed with TNF preparation exhibited a significantly slower disease progression as represented by a lower area under disease progress curve compared to control plant. Disease suppression was obtained at concentration as low as $0.2 \%$. TCE-treated plants were significantly less colonized by Aphis gossypii than control plant.
\end{abstract}

Keywords-Amino acid, Aphis gossypii, compost tea, cucumber mosaic virus, fermented water extract of compost.

\section{INTRODUCTION}

Mosaic virus diseases are widely distributed and cause significant losses on chili pepper throughout the world. In Indonesia, mosaic virus diseases was mainly associated with multiple infection of Cucumber mosaic virus $(C M V)$, Chili veinal mottle virus (ChiVMV), Tobacco mosaic virus (TMV), Pepper yellow leaf curl virus $(P Y L C V)$ and Pepper vein yellowing virus (PeVYV) (Putra et al., 2015). Infected plants show dwarf symptoms and produce curling leaf, mosaic and yellowing. Infection during early growth stage causes dwarfing and dropped flower, fail to produce fruit and can cause total losses. Infection during generative stage causes plant to produce small fruit, hard and have no market value. Yield loss due to viral infection is depending on growth stage and type of symptom. Chili plants with yellowing and mosaic symptom produced $80-84 \%$ less yield compared to those of healthy plant (Sukada et al., 2014).
The use of resistant plants is one of the most efficient, sustainable and frequently employed strategies to control virus infections in fields (Nicaise, 2014). One approach to improving plant resistance to virus disease is to use of resistance inducers of natural origin including living microorganisms, plant extracts, microbial cell-wall extracts, microbial metabolites, minerals, and ions (Aranega-Bou et al., 2014; Llorens et al., 2017; Siah et al., 2018). Numerous studies have demonstrated that plant disease resistance can be induced by treating plant surfaces with a variety of water-based compost preparations, referred to in the literature as compost extract or compost tea (Zhang et al., 1998; Al-Mughrabi et al., 2008; Siddiqui et al., 2009; St. Martin, 2014).

However, compost extract had been reported to have no or a minor control efficacy against viral disease (Kouyoumjian, 2007). Fortification of compost extract may increase its benefit to improve plant resistance against viral infection. Suppression against CMV infection on cigar tobacco was achieved after fortification of a compost extract from vegetable wastes with siderophores-producing Pseudomonas aeruginosa $\mathrm{Ch} 1$ as studied in a greenhouse test (Wahyuni et al., 2010). Fortification of compost with shrimp products resulted in an increase in amino acids content of compost extract (Suwandi, 2013). Soil drench, trunk and foliar spray using the compost extract preparation have known to improve plant tolerance against salt stress (Suwandi et al., 2014) and to recover plant from physiological stress (Suwandi et al., 2018). Over-fermented tempe is one of the inexpensive and abundant source of amino acids in Indonesia that contains more than $19 \%$ of total amino acids (Utami et al., 2016). This study examined the potential used of a fermented water extract of compost fortified with water extract of over-fermented tempe (TCE) to control mosaic disease and its vector Aphis gosypii on potted chili pepper under field condition. 


\section{MATERIAL AND METHODS}

\subsection{Plant material}

CMV free-certified chili cultivar F1 Lado was used throughout experiment. Seedling was prepared on insectfree growth room for 3 weeks. Seedlings were transplanted to a- 15L-black polyethylene bag (polybag) filled with top soil in mixture with fortified compost $(\mathrm{N}$ : $1.0 \mathrm{P}: 6.1 \mathrm{~K}: 5.2 \mathrm{Mg}$ : 8.6). Polybags were placed in 70$\mathrm{cm}$ spacing in the experiment field of Faculty of Agriculture, Sriwijaya University. Plants were fertilized weekly with $250 \mathrm{~mL} /$ plant using $1 \%$ (w/v) a NPK 16-1616 fertilizer. No pesticides were used during the experiment and weeds were cleaned manually.

\subsection{Compost extract and treatment}

Compost extract preparation was produced by fermentation of shrimp waste-enriched compost extract (SWCE) (Suwandi, 2013; Suwandi et al., 2018) in mixture with $20 \%(\mathrm{v} / \mathrm{v})$ water extract of over-fermented tempe and $5 \%(\mathrm{w} / \mathrm{v})$ sucrose. The entire brewer contents were vigorously shaking by hand and then left to ferment in a plastic bottle at ambient temperature for 7 days Three types of preparations, TF, TNF and TFJK were used in the study. TF and TNF used tempe obtained from different production locations in South Sumatra. Juice of Citrus amblycarpa (Hassk.) Ochse (jeruk limau) at 5\% (v/v) was mixed in the TF to produce TFJK preparation. The preparation was applied at concentration 0.2 and $2.0 \%$ by spraying at dosage $600 \mathrm{~L} / \mathrm{Ha}$ started from one week after transplanting at one week interval.

\subsection{Assessment of disease and aphid colonization}

Both disease incidence and severity were measured in the study. Incidence of naturally diseased leaves were counted weekly and calculated as percentage of leaves showing typical mosaic symptom out of total leaves per plant. Severity of naturally occurring mosaic disease was evaluated weekly on a 0 -to-5 scale as follows: $0=$ no symptoms; 1 = mild deformation and mosaic of the youngest two leaves; 2 = pronounced leaf deformation and mosaic of the youngest two leaves, with progression of symptoms into sequentially older leaves; $3=$ pronounced leaf deformation and mosaic progression beyond the two youngest leaves, with all leaves expressing some form of virus-induced symptoms; $4=$ similar symptoms as described for a rating of 3 , with plants also being stunted in growth (where stunting includes both reduced internode extension and smaller leaves); and $5=$ severe stunting, with the majority of leaves being small, severely deformed, and tightly bunched together (Lee and Ryu, 2016). All plants in each treatment were scored; the ratings totaled and were divided by the number of plants multiplied by 5 to give a disease index in percent. Disease progression of each treatment was compared based on area under disease progress curve (AUDPC). The AUDPC of mosaic severity was calculated by using the formula suggested by Simko and Piepho (2012).

Aphid species colonizing the tested plant during experiment were identified according to Blackman and Eastop (2000). Number of aphids was recorded weekly starting from 7 days after transplanting.

\subsection{Experimental design and data analysis}

Experiment was arranged in a completely randomized block factorial design with 15 replications (3 preparations of compost extract $\times 2$ concentrations + one control treatment). Data were analyzed using Proc Glimmix in SAS University Edition 2.7 9.4 M5 (SAS Institute Inc., Cary, NC, USA).

\section{RESULTS}

\subsection{Disease development}

Effect of compost extract treatment on development of mosaic disease was assessed based on incidence of diseased leaves and severity of diseased plants. Incidence of diseased leaves (Fig. 1) and mosaic severity (Fig. 2) were less progressive observed on compost extract treated plot compared to that of water treated plot. Higher disease suppression was exhibited by treatment with TNF preparation and the suppression was similar between a higher concentration (2.0\%) and lower concentration $(0.2 \%)$. Suppression of disease incidence and severity was starting to observe as early as one week after spraying and continuing to a same manner as increasing of plant ages. Regardless of treatments, disease was developed well after 5 weeks of transplanting. Disease protection by TNF and TFJK preparation was prominently observed until 5 weeks after transplanting as restricted disease was found on treated plants. TF preparation induced a similar level of disease progress compared to control, particularly until 5 weeks after transplanting, although a slight suppression of disease was later observed after 6 weeks transplanting. Overall development of diseased severity incidence was less progressive compared to that of disease incidence (Figs. 1 and 2).

Anova of AUDPC of mosaic severity showed that compost extract treated plants resulted in significantly $(P<.0001)$ lower than water treated plant. There was a significant different $(P$ main effect of preparation types $=0.0005$ ) between three preparations used. AUDPC was significantly lower on plants treated with TNF compared than TF and TFJK. Increased concentration from 0.2 to $2.0 \%$ did not significantly affect AUDPC ( $P$ main effect of concentration $=0.0561$ ) of mosaic severity. There was no significant interaction $(P=0.6544)$ between concentration and types of preparation. Based on AUDPC, suppression of disease progress was ranged from 29.6 to $75.4 \%$, respectively. Significant lower 
AUDPC or highest suppression of AUDPC was obtained after application with TNF preparation regardless of the concentration (Table 1).

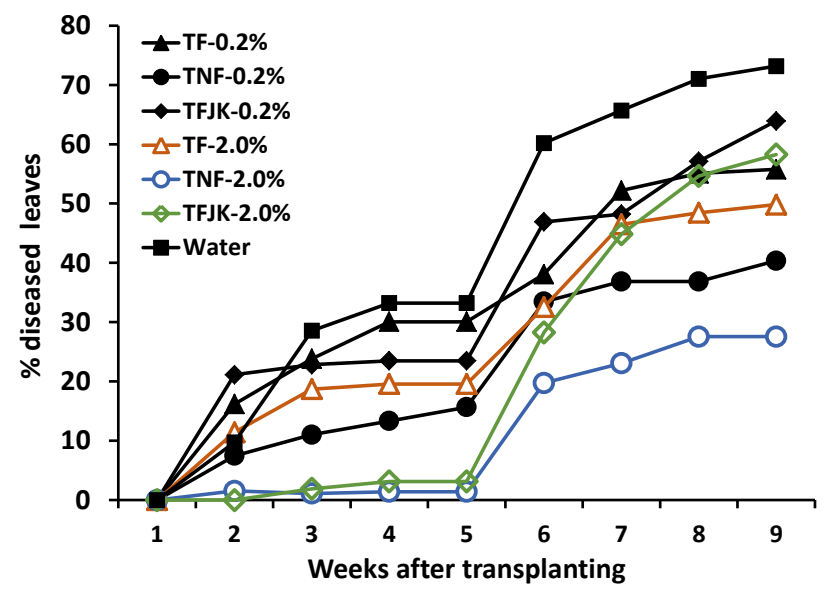

Fig.1: Incidence of diseased leaves on Capsicum annuum sprayed weekly with a variety of fortified-compost extracts

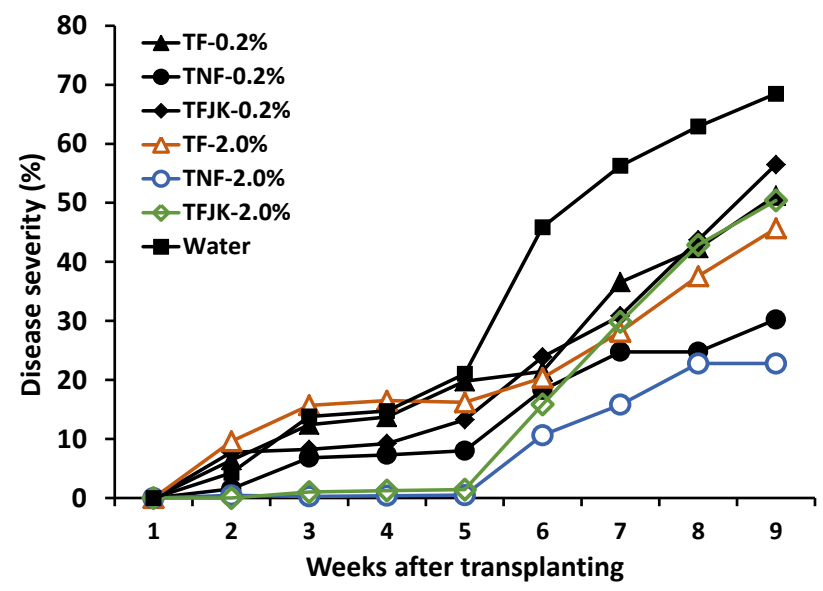

Fig.2: Progress curves of mosaic severity on Capsicum annuum sprayed weekly with a variety of fortified-

compost extracts

Table.1: Area under disease progress curve (AUDPC) of mosaic severity after treatment with compost extract

\begin{tabular}{lcc}
\hline $\begin{array}{c}\text { Treatment of } \\
\text { compost extracts }\end{array}$ & AUDPC $^{1)}$ & $\begin{array}{c}\text { \% disease } \\
\text { suppression } \\
\text { relative to } \\
\text { control }^{2}\end{array}$ \\
\hline TF-0.2\% & $12.48 \pm 1.93 \mathrm{ab}$ & 29.6 \\
TNF-0.2\% & $7.46 \pm 1.79 \mathrm{bc}$ & 57.9 \\
TFJK-0.2\% & $11.56 \pm 1.33 \mathrm{ab}$ & 34.8 \\
TF-2.0\% & $11.68 \pm 2.07 \mathrm{ab}$ & 34.1 \\
TNF-2.0\% & $4.35 \pm 0.51 \mathrm{c}$ & 75.4 \\
TFJK-2.0\% & $8.22 \pm 1.09 \mathrm{bc}$ & 53.6 \\
Water (control) & $17.72 \pm 1.41 \mathrm{a}$ & - \\
\hline
\end{tabular}

${ }^{1)}$ Mean \pm SEM $=$ Mean values \pm standard error of means of fifteen replications. Means within the same column having a common letter(s) do not differ significantly $(P=0.05)$ according to the Tukey HSD-test. $\left.{ }^{2}\right) \%$ disease suppression $=[(A U D P C$ of control - AUDPC of treatment)/ AUDPC of control]*100.

\subsection{Aphid colonization}

Substantial aphid colonization started to observe at 8 and 9 weeks after transplanting. Aphid was found on 77 and 89 of 90 compost extract-treated plants at 8 and 9 weeks after transplanting, respectively. During those periods, colonization was found on all control plants $(100 \%$ colonization). Anova of aphid number per plant showed that compost extract-treated plants resulted in significantly $(P<.0001)$ lower colonization than water treated plant. Type of preparations significantly affected the aphid colonization (P main effect of preparation types $(P<.0001)$ with lower aphid number on plant sprayed with TF and TNF compared to TFJK. Number of aphids colonizing plants sprayed with lower $(0.2 \%)$ and higher (2.0\%) concentration of compost extract were not significantly different $(P=0.1438)$. Effect of compost extract spraying on aphid number was not significantly affected by its concentration ( $P$ interaction between preparation type and concentration $=0.1703)$. When combination of preparation types and concentration was compared, treatment with $0.2 \% \mathrm{TNF}$ and $2.0 \% \mathrm{TF}$ and TNF resulted in lowest aphid colonization (Fig. 3).

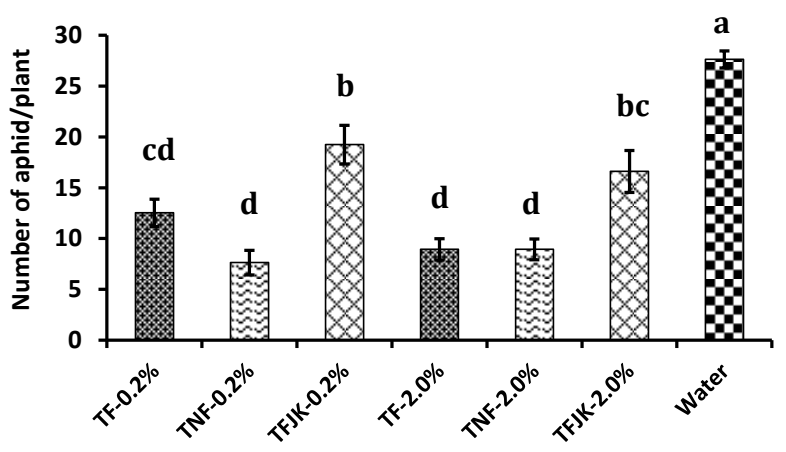

Fig.3: Colonization of aphid at 8 and 9 weeks after transplanting of Capsicum annuum sprayed weekly with a variety of fortified-compost extracts. Bars are means \pm SEM of 15 replicate plants; bars without a letter in common are significantly different $(P=0.05)$ according to the Tukey HSD-test.

\section{DISCUSSION}

In this study, we demonstrated the suppression effects of a compost extract preparation fortified with water extract of over-fermented tempe on mosaic disease and its aphid vector, Aphis gossypii on chili pepper. Plant treated with all three variants of the liquid preparation exhibited in significantly less progressive incidence and severity of mosaic disease and less colonization of A. gossypii 
compared to control plant. Reduction in both diseas e and its vector population was obtained at concentration as low as $0.2 \%$.

Plant treated with a lower concentration $(0.2 \%)$ showed more delayed severity compared to the incidence progress curve. Even though infected, the severity progress had been delayed, suggesting a possible role of bioactive compounds containing in compost extract in plant resistance against viral infection. Compost extract used in the study contain at least 15 kinds of amino acid derived from water extract of over-fermented tempe. Utami et al. (2016) demonstrated that total amino acid contained in water extract of over-fermented tempe was $191 \mathrm{~g} / \mathrm{L}$ and dominated by glutamic and aspartic acid. Amino acids and their metabolites are known to play essential roles during signaling processes as well as in enhancing plant immunity (Zeier, 2013), but few report available regarding induce resistance by exogenous application of amino acids. Exogenous treatment of rice roots with low dose glutamate induced systemic disease resistance against rice blast by regulating salicylic acid signaling pathway in rice leaves (Kadotani et al., 2016). Improved plant resistance against virus following application with amino-acid-based nutritional biostimulant at low concentration has been reported by Betti et al. (1992) demonstrated that. Foliar spray with $0.2-0.3 \%$ the amino acid preparation on chili pepper inoculated with PepMV reduced disease severity of mosaic disease. The viral disease suppression was suggested to be associated with correction of amino acid ratio (GLU+GLN/ASP) imbalance due to viral infection by amino acids contained in the biostimulant.

Disease severity at 8 and 9 weeks after transplanting was positively correlated with number of aphid colonization per plant suggesting that infestation level of the insect vector is responsible for severity of mosaic disease. It was likely that suppression of mosaic severity was associated with insecticidal activity of the fermented extract to Aphis gossypii. The fermentation liquid used in this study was derived from water extract of over-fermented tempe that reported to contain a non-proteinogenic amino acid, aminobutyric acid (Koh et al., 2012). $\quad \beta$-aminobutyric acid (BABA), one of monomer of aminobutyric acid is known to have wide-ranging protection in a number of plant families against a variety of plant pathogens, nematodes and insect herbivores (Alexandersson et al., 2016). BABA has been demonstrated to reduce the performance of the pea aphid, Acyrthosiphon pisum on six legume plant species when applied as a root drench (Hodge et al., 2005). When applied on citrus, BABA was reported to citrus resistance to the Asian citrus psyllid, Diaphorina citri (Tiwari et al., 2013). Cao et al. (2014) suggested that mechanism of BABA-induced resistance in wheat to the grain aphid, Sitobion avenae is associated with direct toxicity of high BABA contents in plant phloem. Further study was needed to determine the role of amino acids contents in aphid suppression of the compost extract. Further study was needed to determine the toxicity of the compost extract on aphid and the role of amino acids contents on aphid performance.

Results from this study suggesting that disease suppression by the compost extract is possibly associated with either enhance host resistance or toxic activity of bioactive compounds containing in compost extract preparation. This findings point to the potential to develop a commercial biopreparation based on fortification of compost extract with amino acid-rich products to manage plant viral diseases. Further determination of bioactive compound and its mode of action need to be studied. Furthermore, the commercial formulation of compost extract preparation also led to successful protection of chili against CMV.

\section{CONCLUSION}

Compost extract preparations fortified with water extract of over-fermented tempe showed suppression effects on either mosaic disease or its aphid vector, Aphis gossypii on chili pepper. Reduction in both disease and its vector population was obtained at concentration as low as $0.2 \%$.

\section{ACKNOWLEDGEMENTS}

The authors received funding from Kemenristekdikti under the Sriwijaya University Priority Applied Research Project 093/SP2H/LT/DPRM/IV/2018.

\section{REFERENCES}

[1] Alexandersson, E., Mulugeta, T., Lankinen, Å., Liljeroth, E., Andreasson, E. (2016). Plant resistance inducers against pathogens in solanaceae speciesFrom molecular mechanisms to field application. International Journal of Molecular Sciences. 17(10):1673. doi:10.3390/ijms 17101673

[2] Al-Mughrabi, K. I., Berthélémé, C., Livingston, T., Burgoyne, A., Poirier, R., and Vikram, A. (2008). Aerobic compost tea, compost and a combination of both reduce the severity of common scab (Streptomyces scabies) on potato tubers. Journal of Plant Sciences. 3:168-175.

[3] Aranega-Bou, P., Leyva, M. D. O, Finiti, I., and García-Agustín, P. (2014). Priming of plant resistance by natural compounds. Hexanoic acid as a model. Frontiers in Plant Science. 5:488. doi:10.3389/fp ls.2014.00488

[4] Betti, L., Canova, A., Paolini, M., Merendino, A., and Maini, P. (1992). Effects of foliar application of an amino-acid-based biostimulant on the response of 
pepper seedlings to PepMV infection. Advances in Horticultural Science. 6:97-103.

[5] Blackman, T.L., and Eastop, V. F. (2000). Aphids on the World's Crops: An Identification and Information Guide, 2nd Edition. Wiley, Chichester, UK, 466 pp.

[6] Cao, H. H, Zhang, M., Zhao, H., Zhang, Y., Wang, X. X., Guo, S. S., Zhang, Z. F., and Liu, T. X. (2014). Deciphering the mechanism of $\beta$ aminobutyric acid-induced resistance in wheat to the grain aphid, Sitobion avenae. PLoS ONE. 9(3):e91768. doi:10.1371/journal.pone.0091768

[7] Hodge, S., Thompson, G. A., and Powell, G. (2005). Application of DL- $\beta$-aminobutyric acid (BABA) as a root drench to legumes inhibits the growth and reproduction of the pea aphid Acyrthosiphon pisum (Hemiptera: Aphididae). Bulletin of Entomological Research. 95:449-455.

[8] Kadotani, N., Akagi, A., Takatsuji, H., Miwa, T., and Igarashi, D. (2016). Exogenous proteinogenic amino acids induce systemic resistance in rice. BMC Plant Biology. 16:60. doi:10.1186/s 12870-0160748-x

[9] Koh, S. P., Jamaluddin, A., Alitheen, N. B., MohdAli, N., Mohd. Yusoff, H., and Long. K. (2012). Nutritional values of tempe inoculated with different strains of Rhizopus: its $\gamma$-aminobutyric acid content and antioxidant property. Journal of Tropical Agriculture and Food Science. 40(2):181-192.

[10] Kouyoumjian, R. (2007). Comparis on of compost tea and biological fungicides for control of early blight in organic heirloom tomato production. $\mathrm{PhD}$ Thesis, Clems on University, South Carolina, USA.

[11] Lee, G. H., and Ryu, C-M. (2016). Spraying of leafcolonizing Bacillus amyloliquefaciens protects pepper from cucumber mosaic virus. Plant Disease. 100(10):2099-2105.

[12] Llorens, E., García-Agustín, P., and Lapeña, L. (2017). Advances in induced resistance by natural compounds: towards new options for woody crop protection. Scientia Agricola. 74(1):90-100.

[13] Nicaise, V. (2014). Crop immunity against viruses: outcomes and future challenges. Frontiers in Plant Science. 25:660. doi:10.3389/fp ls .2014.00660

[14] Putra, I. G. N. B. P., Puspawati, N. M., Nyana, I. D. N., Siadi, I. K., and Suastika, G. (2015). Identification of virus associated with mosaic, yellow, and chlorosis disease on chili pepper (Capsicum frutescens L.). E-Jurnal Agroekoteknologi Tropika (Journal of Tropical Agroecotechnology). 4:3. Retrieved from https://ojs.unud.ac.id/index.php/JAT/article/view/ 17292
[15] Siah, A., Magnin-Robert, M., Randoux, B., Choma, C., Rivière, C., Halama, P., and Reignault, P. (2018). "Natural agents inducing plant resistance against pests and diseases" in Natural Antimicrobial Agents. Sustainable Development and Biodiversity, vol 19, J. M. Mérillon and C. Riviere, Eds. Springer International Publishing AG, 2018, pp. 121-159.

[16] Siddiqui, Y., Meon, S., Ismail, R., and Rahmani, M. (2009). Bio-potential of compost tea from agrowaste to supress Choanephora cucurbitarum L. the causal pathogen of wet rot of okra. Biological Control. 49(1):38-44.

[17] Simko, I., and Piepho, H. (2012). The area under the disease progress stairs: calculation, advantage, and application. Phytopathology. 102:381-389.

[18] St. Martin, C. C. G. (2014). Potential of compost tea for suppressing plant diseases. CAB Reviews. 9(32):1-12.

[19] Sukada, I. W., Sudana, I. M., Nyana, I. D. N., Suastika, G., and Siadi, K. (2014). Effect of infection of some viruses to the decreasing yield on rawit pepper (Capsicum frutescens L.). E-Jurnal Agroekoteknologi Tropika (Journal of Tropical Agroecotechnology). 3:3. Retrieved from https://ojs.unud.ac.id/index.php/ JAT/article/view/9610

[20] Suwandi, S. (2013). Shrimp waste-enriched compost extract, method for production thereof, and use thereof for control plant diseases and improving plant growth. Indonesia Patent ID P000035097.

[21] Suwandi, S., Hamidson, H., and Muslim, A. (2014). Biopriming treatment with enriched compost extract increased growth of rice seedling under salinity stress. Proceeding $2^{\text {nd }}$ National Seminar on Suboptimal Lands: Inclusive agricultural technology for suboptimal lands. Research Center for Suboptimal Lands Sriwijaya University, Palembang, Indonesia. pp. 846-851.

[22] Suwandi, S., Junita, A., Suparman, S., Umayah, A., Hamidson, H., Muslim, A., and Irsan, C. (2018). Curative activity of watery fermented compost extract as a bark treatment against tapping panel dryness. Open Agriculture Journal. 12:74-83.

[23] Tiwari, S., Meyer, W. L, and Stelinski, L. L. (2013). Induced resistance against the Asian citrus psyllid, Diaphorina citri, by $\beta$-aminobutyric acid in citrus. Bulletin of Entomological Research 103:592-600.

[24] Utami, R., Wijaya, C. H., and Lioe, H. N. (2016) Taste of water-soluble extracts obtained from overfermented tempe. International Journal of Food Properties. 19(9):2063-2073.

[25] Wahyuni, W. S., Mudjiharjati, A., Sulistyaningsih, N. (2010). Compost extracts of vegetable wastes as 
biopesticide to control Cucumber Mosaic Virus. HAYATI Journal of Bioscience. 17:95-100.

[26] Zeier, J. (2013). New insights into the regulation of plant immunity by amino acid metabolic pathways. Plant, Cell \& Environment. 36(12):2085-2103.

[27] Zhang, W., Han, D. Y., Dick, W. A., Davis, K. R., and Hoitink, H. A. J. (1998). Compost and compost water extract-induced systemic acquired resistance in cucumber and Arabidopsis. Phytopathology. 88(5):450-455. 